\title{
Thyroid-Stimulating Hormone Reference Ranges in the First Trimester of Pregnancy in an Iodine-Sufficient Country (Endocrinol Metab 2018;33:466-72, Carmen Castillo et al.)
}

\author{
Hyemi Kwon
}

Department of Internal Medicine, Kangbuk Samsung Hospital, Sungkyunkwan University School of Medicine, Seoul, Korea

Since thyroid disease has been associated with adverse pregnancy outcomes, a debate has emerged regarding whether universal thyroid screening in pregnancy should be performed $[1,2]$. Critical to this debate is the wide range in the prevalence of thyroid disorders reported in the literature. The most serious confounding variable is the difficulty in reaching a consensus regarding "normal levels of thyrotropin (thyroid-stimulating hormone [TSH])' in pregnancy. The recent American Thyroid Association (ATA) guidelines recommended that populationbased trimester-specific reference ranges of serum TSH levels should be obtained in a local, euthyroid, pregnant population per trimester, which is considered to be the gold standard [1]. Therefore, the paper of Castillo et al. [3] is a very important study in terms of public health.

Serum TSH level is the most sensitive diagnostic marker of thyroid dysfunction $[4,5]$. TSH level can be influenced by several factors, such as age, sex, thyroid auto-antibodies, race, smoking status, and intake of dietary iodine [4,5]. Dietary iodine intake is an important contributing factor affecting the distribution of serum TSH levels $[5,6]$. A Chinese study reported that the reference interval of serum TSH levels in a mildly iodinedeficient area was 0.33 to $3.42 \mathrm{mIU} / \mathrm{L}$, whereas the reference interval in an iodine-excess area was 0.59 to $5.98 \mathrm{mIU} / \mathrm{L}$ [7].
Thyroid hormone levels of healthy pregnant women differ from those of non-pregnant women because pregnancy has an impact on the thyroid gland and its function [1]. Moreover, a downward shift of the TSH reference range occurs during pregnancy, especially in early pregnancy $[1,2]$. For these reasons, the recent ATA guidelines recommended the population-based trimester-specific reference ranges of serum TSH levels [1]. A previous study in Korea, an iodine-replete area, found that the reference ranges of serum TSH were 0.03 to $4.24 \mathrm{mIU} / \mathrm{L}$ in the first trimester, 0.13 to $4.84 \mathrm{mIU} / \mathrm{L}$ in the second trimester, and 0.30 to $5.57 \mathrm{mIU} / \mathrm{L}$ in the third trimester [2].

Castillo et al. [3] investigated the iodine status of healthy firsttrimester pregnant women in Chile and proposed TSH reference ranges for this population. The median TSH level was $1.99 \mu \mathrm{IU} /$ $\mathrm{mL}$ and the reference range was 0.13 to $5.37 \mu \mathrm{IU} / \mathrm{mL}$ in 670 women of the reference population selected according to the National Academy of Clinical Biochemistry guidelines [3]. The authors found adequate iodine intake and a right-shifted distribution of serum TSH levels in first-trimester pregnant women in Chile [3]. Using the above reference range, the prevalence of subclinical and clinical hypothyroidism in pregnant women was $3.92 \%$ and $1.76 \%$, respectively [3]. This prospective observational study was valuable and well-designed, and it provided

Copyright $\odot 2019$ Korean Endocrine Society

This is an Open Access article distributed under the terms of the Creative Commons Attribution Non-Commercial License (http://creativecommons.org/ licenses/by-nc/4.0/) which permits unrestricted non-commercial use, distribution, and reproduction in any medium, provided the original work is properly cited. 
up-to-date information on the iodine status and thyroid hormone levels of pregnant women in Chile, which has universal salt iodination program.

In the study of Castillo et al. [3], the median urinary iodine (UI) level was $173.45 \mu \mathrm{g} / \mathrm{L}$ in 302 randomly-selected women. Fig. 2 showed the distribution of the various UI levels, indicating that some participants had insufficient iodine intake (UI $<150 \mu \mathrm{g} / \mathrm{L}$ ), while others had more than adequate iodine intake (UI between 150 to $499 \mu \mathrm{g} / \mathrm{L}$ ), and others had excess iodine intake (UI $>500 \mu \mathrm{g} / \mathrm{L}$ ). I wonder the reason that the UI levels were not measured in all participants of the study, and whether the authors evaluated serum TSH levels in subjects categorized by their UI levels.

A recent meta-analysis on the prevalence of thyroid disease in pregnancy reported that the overall pooled estimates of prevalence for overt hypothyroidism and subclinical hypothyroidism were $0.5 \%$ and $3.47 \%$, respectively, among studies using a 2.5 th to 97.5th percentile TSH reference range [8]. Based on that result, the prevalence of overt hypothyroidism in Chilean pregnant women seems to be higher than that reported from other countries, despite of the similar prevalence of subclinical disease. Whether this discrepancy is due to differences in the free thyroxine assay or a true increase in prevalence, further researches are needed.

Nonetheless, this study provides important information on the TSH reference range during pregnancy in an iodine-sufficient area. I would like to congratulate the authors on this excellent result and expect many further valuable studies to be conducted in the future.

\section{CONFLICTS OF INTEREST}

No potential conflict of interest relevant to this article was reported.

\section{ORCID}

Hyemi Kwon https://orcid.org/0000-0003-4257-3133

\section{REFERENCES}

1. Alexander EK, Pearce EN, Brent GA, Brown RS, Chen H, Dosiou C, et al. 2017 Guidelines of the American Thyroid Association for the diagnosis and management of thyroid disease during pregnancy and the postpartum. Thyroid 2017; 27:315-89.

2. Kim HJ, Cho YY, Kim SW, Kim TH, Jang HW, Lee SY, et al. Reference intervals of thyroid hormones during pregnancy in Korea, an iodine-replete area. Korean J Intern Med 2018; 33:552-60.

3. Castillo C, Lustig N, Margozzini P, Gomez A, Rojas MP, Muzzo S, et al. Thyroid-stimulating hormone reference ranges in the first trimester of pregnancy in an iodine-sufficient country. Endocrinol Metab (Seoul) 2018;33:466-72.

4. Hollowell JG, Staehling NW, Flanders WD, Hannon WH, Gunter EW, Spencer CA, et al. Serum TSH, T(4), and thyroid antibodies in the United States population (1988 to 1994): National Health and Nutrition Examination Survey (NHANES III). J Clin Endocrinol Metab 2002;87:489-99.

5. Teng W, Shan Z, Teng X, Guan H, Li Y, Teng D, et al. Effect of iodine intake on thyroid diseases in China. N Engl J Med 2006;354:2783-93.

6. Jeon MJ, Kim WG, Kwon H, Kim M, Park S, Oh HS, et al. Excessive iodine intake and thyrotropin reference interval: data from the Korean National Health and Nutrition Examination Survey. Thyroid 2017;27:967-72.

7. Guan H, Shan Z, Teng X, Li Y, Teng D, Jin Y, et al. Influence of iodine on the reference interval of TSH and the optimal interval of TSH: results of a follow-up study in areas with different iodine intakes. Clin Endocrinol (Oxf) 2008; 69:136-41.

8. Dong AC, Stagnaro-Green A. Differences in diagnostic criteria mask the true prevalence of thyroid disease in pregnancy: a systematic review and meta-analysis. Thyroid 2019;29: 278-89. 